\title{
IRRIGATION WITH SALINE WATER AND NITROGEN IN PRODUCTION COMPONENTS AND YIELD OF SUNFLOWER ${ }^{1}$
}

\author{
JOÃO BATISTA DOS SANTOS ${ }^{2 *}$, DOROTEU HONÓRIO GUEDES FILHO ${ }^{2}$, HANS RAJ GHEYI $^{3}$, GEOVANI \\ SOARES DE LIMA ${ }^{2}$, LOURIVAL FERREIRA CAVALCANTE ${ }^{4}$
}

\begin{abstract}
Due to the quantitative and qualitative limitation of water resources, saline water irrigation and nitrogen $(\mathrm{N})$ fertilisation can contribute positively to the expansion of sunflower cultivation in the semiarid region of Northeast Brazil. Thus, this study aimed to evaluate production components and yield of sunflower, cv. 'Embrapa 122-V2000', irrigated with waters of different salinity levels (electrical conductivity - ECw) and fertilised with varying amounts of $\mathrm{N}$ in a field experiment in an eutrophic Quartzarenic Neosol from November 2012 to February 2013. The experiment was performed in a completely randomised block design in split plots, in a $5 \times 4$ factorial scheme, which corresponded to five ECw levels $\left(0.15,1.5,2.5,3.5\right.$ and $\left.4.5 \mathrm{dS} \mathrm{m}^{-1}\right)$ and four $\mathrm{N}$ levels $\left(60,80,100\right.$ and $\left.120 \mathrm{~kg} \mathrm{ha}^{-1}\right)$, with three replicates and 30 plants per plot. The interaction between water salinity levels and $\mathrm{N}$ did not have significant effects on the studied variables; irrigation water salinity had isolated negative effects on the total number of achenes, number of viable achenes, productivity and oil yield of achenes. The increase in $\mathrm{N}$ levels stimulated the total number and the number of viable achenes, the mass of 1,000 achenes, capitulum diameter and productivity of achenes of sunflower, cv. 'Embrapa 122-V2000', but had no effect on the oil content of achenes. $\mathrm{N}$ levels of up to $100 \mathrm{~kg} \mathrm{ha}^{-1}$ promoted adequate oil content in the achenes of sunflower, cv 'Embrapa 122-V2000'.
\end{abstract}

Keywords: Helianthus annuus L.. Oilseed plant. Salinity. Nitrogen.

\section{IRRIGAÇÃO COM ÁGUA SALINA E ADUBAÇÃO NITROGENADA NOS COMPONENTES DE PRODUÇÃO E RENDIMENTO DO GIRASSOL}

RESUMO - Diante da diminuição quantitativa e qualitativa de recursos hídricos, a irrigação com água salina e a adubação nitrogenada podem contribuir de forma positiva para a expansão do cultivo de girassol na região semiárida do Nordeste brasileiro. Deste modo objetivou-se com este trabalho avaliar os componentes de produção e o rendimento do girassol, cv. Embrapa 122-V2000, irrigado com águas de diferentes salinidades (condutividade elétrica - CEa) e níveis de nitrogênio no solo, em experimento de campo conduzido em um Neossolo Quartezarênico eutrófico no período de novembro de 2012 a fevereiro de 2013. O delineamento foi em blocos casualizados analisados em parcelas subdivididas, no arranjo fatorial $5 \mathrm{x} 4$, relativo a cinco níveis de CEa: 0,$15 ; 1,5 ; 2,5 ; 3,5$ e 4,5 dS m${ }^{-1}$ e quatro níveis de nitrogênio de $60,80,100$ e $120 \mathrm{~kg} \mathrm{ha}^{-1}$, com três repetições e 30 plantas por parcela. A interação entre os níveis de salinidade da água de irrigação e de nitrogênio não exerceu efeitos significativos sobre as variáveis estudadas; os efeitos isolados da salinidade das águas de irrigação inibiram o número total de aquênios, o número de aquênios viáveis, a produtividade e o rendimento em óleo dos aquênios. $\mathrm{O}$ aumento dos níveis de nitrogênio, exceto sobre o teor de óleo dos aquênios, estimulou o número de aquênios total e viáveis, a massa de mil aquênios, o diâmetro do capítulo e a produtividade de aquênios do girassol cv. Embrapa 122-V2000. O nível de $\mathrm{N}$ de até $100 \mathrm{~kg} \mathrm{ha}^{-1}$ proporcionou teor adequado de óleo nos aquênios de girassol cv. Embrapa 122-V2000.

Palavras-chave: Helianthus annuus L.. Oleaginosa. Salinidade. Nitrogênio.

\footnotetext{
*Corresponding author

${ }^{1}$ Received for publication in $05 / 06 / 2015$; accepted in $04 / 22 / 2016$

Paper extracted from the doctoral thesis of the second author.

${ }^{2}$ Center of Technology and Natural Resources, Universidade Federal de Campina Grande, Campina Grande, PB, Brazil: agrosantos@hotmail.com, doroteufilho@hotmail.com, geovanisoareslima@gmail.com.

${ }^{3}$ Nucleus of Soil and Water Engineering, Universidade Federal do Recôncavo da Bahia, Cruz das Almas, BA, Brazil; hans@pq.cnpq.br.

${ }^{4}$ Department of Soil Science and Agricultural Engineering, Universidade Federal da Paraíba, Areia, PB, Brazil; lofeca@cca.ufpb.br.
} 


\section{INTRODUCTION}

Sunflower (Helianthus annuus L.) is an annual dicotyledonous plant from the Asteraceae family, originated from North America, and cultivated in all continent. The main producers are Russia, Ukraine, Argentina and Middle Eastern countries. It can be cultivated in all regions of Brazil because its development and yield are little influenced by latitude, altitude and photoperiod (ZOBIOLE et al., 2010). H. annuus is a multipurpose species whose main products are the achenes intended for the extraction of oil for human consumption and for biodiesel production, to complement animal diets and as an ornamental plant (RODRIGUES et al., 2010).

Despite the variability in sunflower exploitation, in semiarid areas, water and soil salinity inhibit the growth and yield of most crops. Especially for $H$. annuus, high salt concentrations in the water or the soil, besides reducing water potential, cause toxic effects and lead to functional and metabolic disorders (SILVA et al., 2009), resulting in growth inhibition and yield and quality losses of achenes and oil. This situation is frequent in oilseed crops in which the harmful effects of salinity compromise the development, as reported by Correia et al. (2009) for peanuts (Arachis hipógea); Lima et al. (2014) for papaya and Nobre et al. (2010) and Guedes Filho et al. (2011) for sunflower.

Adequate nutritional supply stands out as a criterion for yield and profitability increase in plantations, and $\mathrm{N}$ is the macronutrient required in the largest amounts by most crops (LAVRES JUNIOR et al., 2005), mainly because N participates in the formation of proteins, amino acids and other compounds that are vital for plant metabolism. In addition, $\mathrm{N}$ plays an important role in the metabolism and nutrition of crops and is the most required nutrient by sunflowers (SACHS et al., 2006).

$\mathrm{N}$ deficiency causes nutritional disorders; however, in $H$. annuus, $\mathrm{N}$ excess leads to losses in oil yield, increase in incidence of pests and diseases and damaged achenes (SMIDERLE, 2000). Biscaro et al. (2008) claim that the number of achenes per capitulum is influenced by $\mathrm{N}$ fertilisation with maximum response at the dose of $46 \mathrm{~kg} \mathrm{ha}^{-1}$. According to these authors, the factors responsible for adequate capitulum development, with a high number of viable flowers and, consequently, higher number of viable achenes, are the sowing period, high-quality biological material, frequency of pollination agents, adequate management of soil fertilisation, especially $\mathrm{N}$ levels, and control of pests and diseases.

Selective ion absorption can be an alternative to regulate osmotic stress in plants, because tolerant plants have the capacity to absorb essential nutrients from the saline solution, where the concentration of non-essential ions (toxic) is higher (FAGERIA, 1989). In this context, Flores et al. (2001) highlight that there are evidences of competition in the absorption of nitrate and chloride, so that an increase in nitrate concentration in the root zone can inhibit greater chloride absorption.

This study aimed to evaluate the effects of irrigation water salinity and $\mathrm{N}$ levels applied to the soil on the production components and oil yield of sunflower.

\section{MATERIAL AND METHODS}

A field experiment was carried out from November 2012 to February 2013 at the Macaquinhos Farm, located $8 \mathrm{~km}$ south of the municipality of Remígio, Paraíba, Brazil. The municipality is inserted in the microregion of 'Curimataú Ocidental' situated at the geographic coordinates of $6^{\circ} 53^{\prime} 00^{\prime}$ ' $\mathrm{S}$ and $36^{\circ} 02^{\prime} 00^{\prime}$ ' $\mathrm{W}$, and a mean altitude of $470 \mathrm{~m}$. The climate in the region, according to Köppen's classification adapted to Brazil (COELHO; SONCIN, 1982) is "CSa", semi-humid, with hot and dry summers and a rainy period from March to July.

The soil in the experimental area, according to the norms of the Brazilian Soil Classification System, is eutrophic Quartzarenic Neosol and, according to the methodologies suggested by the Brazilian Agricultural Research Corporation EMBRAPA (DONAGEMA et al., 2011), in the layer of 0-20 cm showed a sandy texture with contents of $88.97,9.06$ and $1.97 \%$ respectively of sand, silt and clay. Soil chemical characteristics are: Organic matter $(\mathrm{OM})=1.14 \mathrm{~g} \mathrm{dm}^{-3} ; \mathrm{pH}\left(\mathrm{H}_{2} \mathrm{O}\right)=5.63 ; \mathrm{P}=$ $5.06 \mathrm{mg} \mathrm{dm}{ }^{-3} ; \mathrm{K}=0.22 \mathrm{cmol}_{\mathrm{c}} \mathrm{kg}^{-1} ; \mathrm{Al}^{3+}=0.53 \mathrm{cmol}_{\mathrm{c}}$ $\mathrm{kg}^{-1} ; \mathrm{H}^{+}+\mathrm{Al}^{3+}=1.59 \mathrm{cmol}_{\mathrm{c}} \mathrm{kg}^{-1} ; \mathrm{Ca}^{2+}=1.73 \mathrm{cmol}_{\mathrm{c}}$ $\mathrm{kg}^{-1} ; \mathrm{Mg}^{2+}=0.98 \mathrm{cmol}_{\mathrm{c}} \mathrm{kg}^{-1} ; \mathrm{Na}^{+}=1.04 \mathrm{cmol}_{\mathrm{c}} \mathrm{kg}^{-1}$, sum of bases $=3.97 \mathrm{cmol}_{\mathrm{c}} \mathrm{kg}^{-1}$, cation exchange capacity $=5.56 \mathrm{cmol}_{\mathrm{c}} \mathrm{kg}^{-1}$, base saturation percentage $=71.4 \%$ and electrical conductivity of the saturation extract - ECse $=0.97 \mathrm{dS} \mathrm{\textrm {m } ^ { - 1 }}$. The eutrophic character occurs because the soil was cultivated with 'Baixinho de Santa Amália' papaya (MESQUITA et al., 2010), followed by citrus cultivation until two years before sunflower planting.

The treatments were distributed in randomised blocks in split plots, in a $5 \times 4$ factorial scheme, which corresponded to five levels of irrigation water salinity $(\mathrm{ECW}-0.15,1.5,2.5,3.5$ and $\left.4.5 \mathrm{dS} \mathrm{m}^{-1}\right)$ and four $\mathrm{N}$ levels $(60,80,100$ and $\left.120 \mathrm{~kg} \mathrm{ha}^{-1}\right)$, with three replicates. Plots corresponded to the salinity levels and subplots to $\mathrm{N}$ levels. The plots had dimensions of $4.0 \times 3.0 \mathrm{~m}$, totalling $12 \mathrm{~m}^{2}$, with 30 plants per experimental unit in 3 rows with the spacing of $0.40 \mathrm{~m}$ between plants and $1.0 \mathrm{~m}$ between rows. The cultivar 'Embrapa 122-V2000' was used due to its precocity, yield and oil content as well as achene quality, according to 
EMPRABA (2006).

Before planting, harrowing was performed three times; two times with a disc harrow at a depth of $30 \mathrm{~cm}$ and once with a levelling harrow. The planting furrows received $0.5 \mathrm{~kg} \mathrm{~m}^{-1}$ of cattle manure 30 days before sowing, due to the low content of organic matter and the sandy texture of the soil. The cattle manure was analysed according to the methodology of Embrapa (1999), with the following results: $\mathrm{pH}\left(\mathrm{H}_{2} \mathrm{O}\right)=8.76 ; \mathrm{P}=5.47 \mathrm{mg} \mathrm{dm}^{-3} ; \mathrm{K}=$ $10.25 \mathrm{mg} \mathrm{dm}{ }^{-3} ; \mathrm{H}+\mathrm{Al}^{3+}=0 \mathrm{cmol}_{\mathrm{c}} \mathrm{kg}^{-1} ; \mathrm{Ca}^{2+}=8.80$ $\mathrm{cmol}_{\mathrm{c}} \mathrm{kg}^{-1} ; \mathrm{Mg}^{2+}=13.34 \mathrm{cmol}_{\mathrm{c}} \mathrm{kg}^{-1} ; \mathrm{Na}^{+}=2.47$ $\mathrm{cmol}_{\mathrm{c}} \mathrm{kg}^{-1} ; \mathrm{OM}=510 \mathrm{~g} \mathrm{dm}^{-3} ; \mathrm{C}=295 \mathrm{~g} \mathrm{dm}^{-3} ; \mathrm{N}=$ $16.3 \mathrm{~g} \mathrm{dm}^{-3}$ and $\mathrm{C} / \mathrm{N}$ ratio $=18: 1$. Basal fertilisation was performed using $80 \mathrm{~kg} \mathrm{ha}^{-1}$ of $\mathrm{P}_{2} \mathrm{O}_{5}$ and $2 \mathrm{~kg} \mathrm{ha}^{-1}$ of boron using single superphosphate and boric acid, respectively. $\mathrm{N}$ fertilisation with urea was applied according to the treatments. Potassium fertilisation corresponded to $80 \mathrm{~kg} \mathrm{ha}^{-1}$ of $\mathrm{K}_{2} \mathrm{O}$ in the form of potassium chloride. Both fertilisations (nitrogen and potassium) were divided into three, applying one third at planting and the rest in two equal applications at 20 and 40 days after emergence (DAE) of the seedlings.

Irrigation water, at each salinity level, was prepared $24 \mathrm{~h}$ before irrigation, dissolving non-iodised sodium chloride with $96 \%$ purity in water from surface source adopting the procedure recommeded by Rhoades et al. (2000), using a digital portable conductivity meter for electrical conductivity measurements. The water used in the preparation of the different salinity levels was pumped to a $50 \mathrm{~m}^{3}$ masonry tank and then transported and stored in covered containers with capacity for $3 \mathrm{~m}^{3}$, in which each type of water with different salinity levels was prepared according to the treatments. Screen filters were installed at the outlet of each container in order to avoid emitter clogging by the suspended particles present in the irrigation water. Irrigation was performed through gravity at service pressure of $0.02 \mathrm{MPa}$, every two days, using a localised irrigation system with a drip tape along which the emitters were distributed every $20 \mathrm{~cm}$, each with flow rate of $6.0 \mathrm{~L} \mathrm{~h}^{-1}$, from sowing on. Irrigation depth was calculated based on the estimated Reference Evapotranspiration (ETo), using data from the weather station of the Center of Agricultural Sciences of the Federal University of Paraíba, Campus II, Areia-PB, located close to the experimental area, and on crop coefficients $(\mathrm{Kc})$ along the sunflower cycle.

Sowing was manually performed, with eight seeds planted in each hole at a depth of $1 \mathrm{~cm}$. At 10 DAE, the first thinning was performed, leaving the three most vigorous plants per hole and, at 15 DAE, another thinning was performed, leaving only the most vigorous plant per hole. At 30 DAE, weeding was performed using a hoe, and insecticide Provado 200 Sc [1-(6-chloro-3-pyridylmethyl)-Nnitroimidazolidin-2-y lideneamine] at a dose of
$0.35 \mathrm{~L} \mathrm{ha}^{-1}$ (diluted in $100 \mathrm{~L}$ of water) for whitefly control (Bemisia tabaci).

Harvest was performed at 90 DAE, when plants reached the stage of physiological maturation of achenes called "R9", i.e. when they were inclined downward, with the back and bracts coloured from yellow to brown (CONNOR; HALL, 1997). The following variables were evaluated: total number of achenes (TNA), through the manual count of all achenes on the capitulum; number of viable achenes (NVA), i.e. full achenes; percentage of viable achenes (\% VA), calculated through the relationship of NVA/TNA; external capitulum diameter (DCAP), measured at $90 \mathrm{DAE}$ in the harvest period with a millimeter ruler; mass of one thousand viable achenes $(\mathrm{M} 1000 \mathrm{~A})$ and the productivity of achenes $\left(\mathrm{PRO}-\mathrm{kg} \mathrm{ha}^{-1}\right)$, calculated based on the production of the experimental plots, with water content of achenes corrected to $13 \%$. The oil content of the achenes was determined through nuclear magnetic resonance (NMR) spectroscopy, which is based on the property of atomic nuclei of absorbing energy when excited and oscillate in a magnetic field (PAZ, 1996). Oil yield in $\mathrm{kg} \mathrm{ha}^{-1}$ was estimated by the equation below, as used by Guedes Filho et al. (2015):

$\mathrm{OY}=\mathrm{P} \times \mathrm{OC} / 100$

where $\mathrm{OY}=$ Oil yield $\left(\mathrm{kg} \mathrm{ha}{ }^{-1}\right) ; \mathrm{P}=$ productivity $\left(\mathrm{kg} \mathrm{ha}^{-1}\right) ; \mathrm{OC}=$ oil content $(\%)$.

The data were subjected to analysis of variance (ANOVA) by $\mathrm{F}$ test at 0.01 and 0.05 probability levels and quantitatively analysed through regression using the statistical program SISVAR-ESAL (FERREIRA, 2011).

\section{RESULTS AND DISCUSSION}

According to the analysis of variance (Table 1), the interaction between water salinity and $\mathrm{N}$ levels did not have significant effects on any of the studied variables; the percentage of viable achenes did not suffer interference from any source of variation; the total number of achenes (TNA) and the number of viable achenes (NVA) were influenced $(p<0.01)$ by the isolated effects of the levels of water salinity and $\mathrm{N}$ supplied to the soil, and capitulum diameter (DCAP) responded to the effects of $\mathrm{N}$ levels.

Water salinity did not affect capitulum diameter (DCAP), which responded significantly to the effects of $\mathrm{N}$ levels applied as top-dressing (Table 1). The absence of a significant effect of water salinity - ECW on the production of viable achenes (VA) and external capitulum diameter (DCAP) may be due to the sandy texture of the soil, possibly promoting greater nutrient absorption and causing increases in growth and, consequently, in sunflower production. 
Table 1. ANOVA summary for the total number of achenes (TNA), number of viable achenes (NVA), percentage of viable achenes (\% VA) and external capitulum diameter (DCAP) of sunflower, cv. 'Embrapa 122-V2000', cultivated under different levels of irrigation water salinity and nitrogen fertilisation.

\begin{tabular}{|c|c|c|c|c|c|}
\hline \multirow{2}{*}{ Variation source } & \multirow[b]{2}{*}{ DF } & \multicolumn{4}{|c|}{ Mean square } \\
\hline & & TNA & NAV & $\% \mathrm{VA}$ & DCAP \\
\hline Blocks & 2 & $71155.55^{\text {ns }}$ & $57801.21^{\mathrm{ns}}$ & $20.40^{\mathrm{ns}}$ & $15.61^{\mathrm{ns}}$ \\
\hline Salinity (S) & 4 & $241781.23^{* *}$ & $199092.48^{* *}$ & $12.52^{\text {ns }}$ & $11.09^{\mathrm{ns}}$ \\
\hline Linear regression & 1 & $944866.48^{* *}$ & $775168.78^{* *}$ & $0.69^{\text {ns }}$ & $40.32^{\mathrm{ns}}$ \\
\hline Quadratic regression & 1 & $5625.98^{\text {ns }}$ & $245.51^{\mathrm{ns}}$ & $34.31^{\mathrm{ns}}$ & $0.37^{\mathrm{ns}}$ \\
\hline Residue 1 & 8 & 33187.93 & 24682.38 & 12.23 & 7.22 \\
\hline Nitrogen $(\mathrm{N})$ & 3 & $239570.44^{* *}$ & $211569.21^{* *}$ & $4.56^{\mathrm{ns}}$ & $42.49^{* *}$ \\
\hline Linear regression & 1 & $596926.41^{* *}$ & $521250.08^{* *}$ & $9.68^{\mathrm{ns}}$ & $116.93^{* *}$ \\
\hline Quadratic regression & 1 & $79206.67^{\mathrm{ns}}$ & $76826.82^{\mathrm{ns}}$ & $3.79^{\mathrm{ns}}$ & $5.70^{\mathrm{ns}}$ \\
\hline Residue 2 & 30 & 25538.45 & 24131.03 & 11.29 & 3.72 \\
\hline Interaction $(\mathrm{S} \times \mathrm{N})$ & 12 & $13288.01^{\mathrm{ns}}$ & $11461.66^{\mathrm{ns}}$ & $2.78^{\mathrm{ns}}$ & $2.13^{\mathrm{ns}}$ \\
\hline CV $1(\%)$ & & 19.73 & 18.71 & 3.85 & 16.87 \\
\hline CV2 (\%) & & 17.31 & 18.50 & 3.70 & 12.12 \\
\hline
\end{tabular}

$\mathrm{DF}=$ degrees of freedom; CV1 = coefficient of variation of the plots; CV2 = coefficient of variation of the subplots; $*$ and $* *=$ significant at 0.01 and 0.05 probability levels, respectively; ns $=$ not significant.

The increase in the saline level of the irrigation water linearly decreased the total number of achenes by 82.75 achenes per unit increase in ECw. The values decreased from 1,112 to 752 achenes, indicating a loss of $7.36 \%$ per unit increase in water salinity level (Figure 1A). The reduction in the number of achenes results from salt damage, inhibiting plant growth and, consequently, the production, which is reflected in yield loss. Under saline conditions, water availability was reduced due

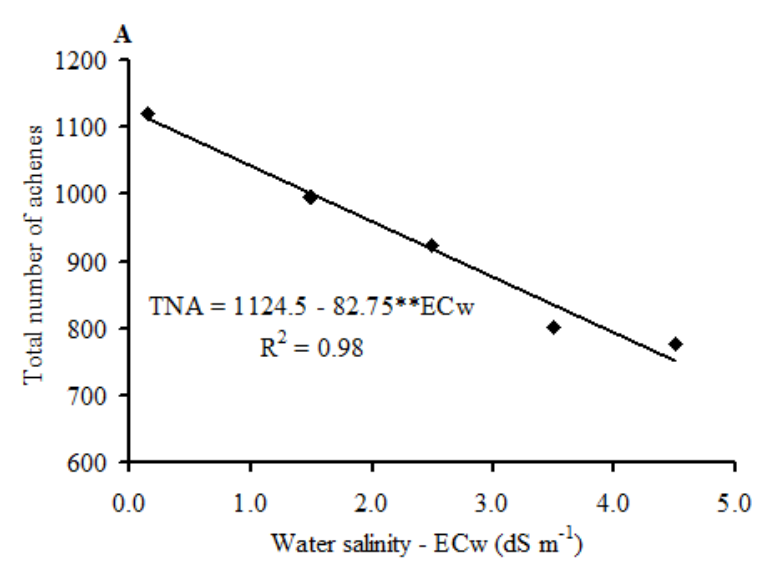

to the decrease in the osmotic potential of the soil solution, forcing the plant to invest more vital reserves, such as sugars and carbohydrates, to absorb water and nutrients for growth and production (MUNNS; TESTER, 2008). A similar situation was reported by Travassos et al. (2011), who observed losses of $9.64 \%$ per unit increase in water salinity, using the same sunflower cultivar under irrigation with water of salinity ranging from 0.5 to $5.0 \mathrm{dS} \mathrm{m}^{-1}$.

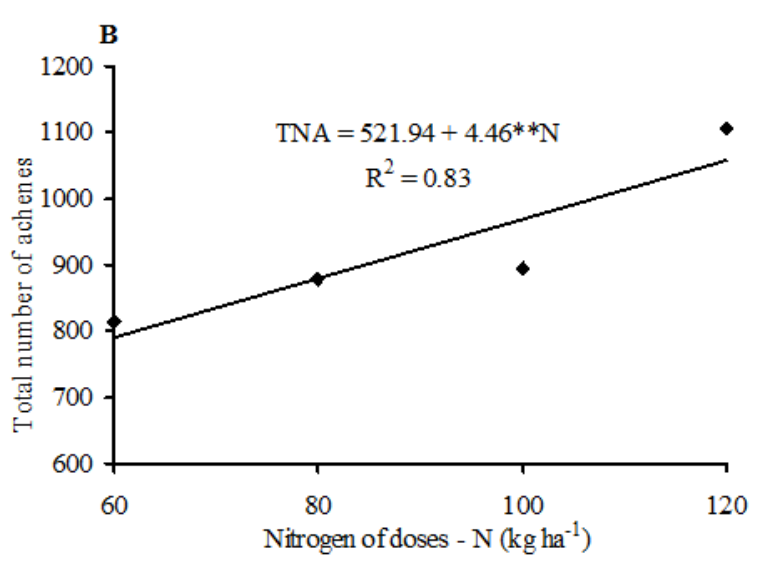

Figure 1. Total number of achenes of sunflower cv. 'Embrapa 122-V2000' as a function of irrigation water salinity (A) and nitrogen fertilisation (B).

In contrast to the factor irrigation water salinity, $\mathrm{N}$ levels linearly stimulated the production of achenes, with an increment of 4.46 achenes per unit increase in $\mathrm{N}$ levels (Figure 1B), i.e. 17.09\% of increment for every $20 \mathrm{~kg} \mathrm{ha}^{-1}$ of $\mathrm{N}$ applied, from 60 $\mathrm{kg} \mathrm{ha}^{-1}$ onwards. Considering that the increase in water salinity from $0.15 \mathrm{dS} \mathrm{m}^{-1}$ onwards inhibited the production of achenes and the increase in $\mathrm{N}$ levels stimulated the increment in the same variable, $\mathrm{N}$ must mitigate the effects of salts on sunflower, especially if the plant is adequately supplied with the nutrient. With regard to the action of the isolated effects of $\mathrm{N}$, the results are consistent with the findings of Campos et al. (2012), who claimed that the absence of $\mathrm{N}$ compromised the number of achenes in relation to plants treated with $100 \mathrm{~kg} \mathrm{ha}^{-1}$ of the element, with values of 145 and 570 achenes per capitulum, indicating a loss of $74.6 \%$. Such reduction shows the need for $\mathrm{N}$ in the functions that are vital to plants, under any form of cultivation, especially when subjected to saline stress. It also evidences that plants that are nutritionally balanced with respect to this macronutrient suffer less degenerative effects of salinity compared with $\mathrm{N}$-deficient plants. The results are consistent with those reported by Freitas et al. (2012), who concluded that sunflower growth and production components respond positively to $\mathrm{N}$ fertilisation, and 
by Malik et al. (2009), who obtained 161 and 283 achenes per capitulum in sunflower plants without and with $130 \mathrm{~kg} \mathrm{ha}^{-1}$ of $\mathrm{N}$, respectively.

The number of viable achenes per capitulum as well as the total number of achenes per capitulum decreased with the increase in water salinity and increased with higher $\mathrm{N}$ levels (Figure 2). The values decreased from 1,011 to 685 achenes, with loss of $7.33 \%$ per unit increase in ECW (Figure 2A), indicating that sunflower is sensitive to the salinity of the irrigation water. With the continuous irrigations, soil salinity must have reached a level not

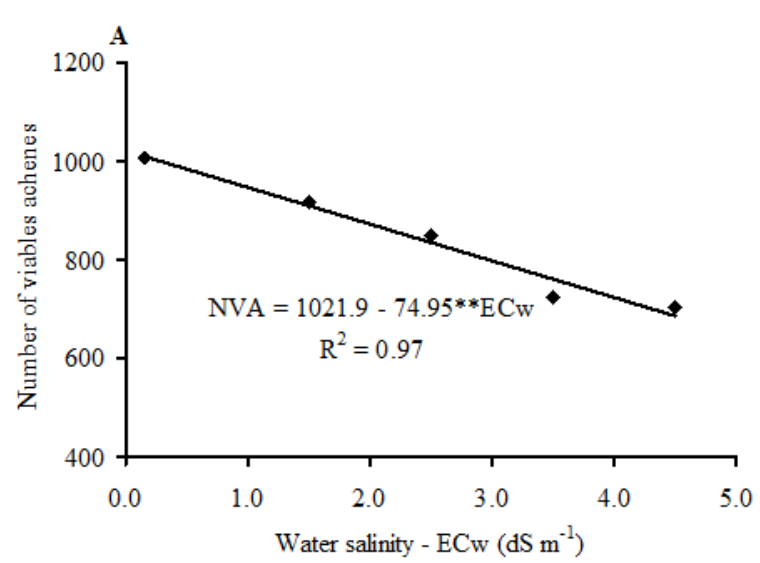

tolerated by the crop and, consequently, compromised its production when irrigated even with water of salinity considered as without restriction to most cultivated plants (AYERS; WESTCOT, 1999). A similar behaviour was reported by Santos Júnior et al. (2011), who observed losses of $11 \%$ per unit increase in the salinity of the nutrient solution for the sunflower cultivar 'Embrapa 122-V2000' in a semi-hydroponic system with water salinity ranging from 1.7 to $11 \mathrm{dS}$ $\mathrm{m}^{-1}$, in a protected environment.

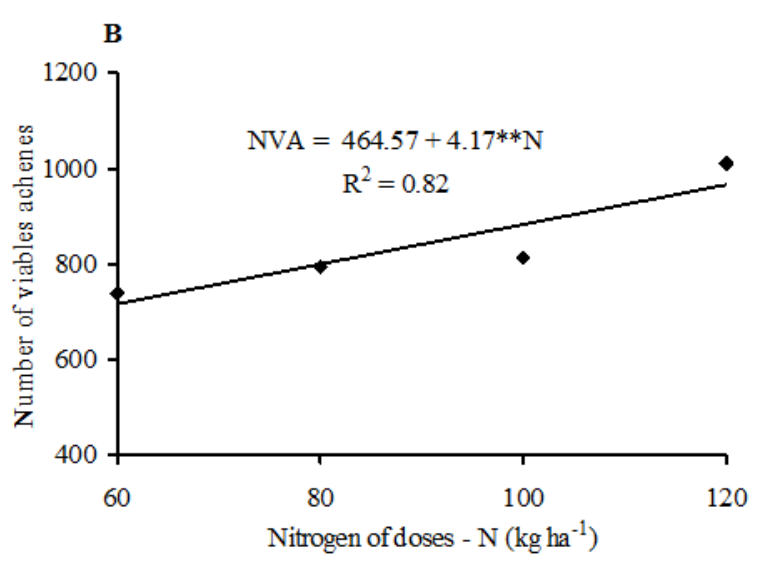

Figure 2. Number of viable achenes in sunflower cv. 'Embrapa 122-V2000' as a function of irrigation water salinity (A) and nitrogen fertilisation (B).

Regarding $\mathrm{N}$ fertilisation (Figure 2B), the increment in $\mathrm{N}$ levels increased from 715 to 965 viable achenes produced by plants fertilised with the lowest and the highest $\mathrm{N}$ levels $(60$ and $120 \mathrm{~kg}$ of $\mathrm{N}$ $\mathrm{ha}^{-1}$ ), respectively, inducing a gain of $17.95 \%$ for every $20 \mathrm{~kg} \mathrm{ha}^{-1}$ of $\mathrm{N}$ applied from $60 \mathrm{~kg} \mathrm{ha}{ }^{-1}$ onwards (Figure 2B). The increase in the number of viable achenes is attributed to the $\mathrm{N}$ functions in the plant metabolism, as a constituent of the chlorophyll molecule, proteins, amino acids and others (TAIZ; ZEIGER, 2013), stimulating the growth and yield of the crops (CHAVES et al., 2011). Comparatively, our results are lower than those reported by Guedes Filho et al. (2011) in sunflower irrigated with saline waters and increasing $\mathrm{N}$ levels ( 0 to $100 \mathrm{~kg} \mathrm{ha}^{-1}$ of $\mathrm{N}$ ); these authors observed increments of about $65 \%$ in the production of viable achenes.

The external capitulum diameter of sunflower did not respond to the effects of the interaction of water salinity $\mathrm{x} \mathrm{N}$ levels or to the increase in water salinity, but increased with the increment in the $\mathrm{N}$ levels applied to the soil. For the factor $\mathrm{N}$ levels, the data best fitted to a positive linear model, according to the regression equation (Figure 3), with increment from 13.91 to $17.51 \mathrm{~cm}$ in relation to the lowest and highest $\mathrm{N}$ levels (60 and $120 \mathrm{~kg}$ of $\mathrm{N} \mathrm{ha}^{-1}$ ), which represented an increase of $11.64 \%$ for every $20 \mathrm{~kg} \mathrm{ha}^{-1}$ of $\mathrm{N}$ applied to the soil, between the levels of 60 and $120 \mathrm{~kg} \mathrm{ha}^{-1}$. Although lower than 19.9 and $22.4 \mathrm{~cm}$, obtained by Lobo and Grassi Filho (2007) in the soil without and with $50 \mathrm{~kg} \mathrm{ha}^{-1}$ of $\mathrm{N}$, these values surpass the value of $11.9 \mathrm{~cm}$ in the capitulum diameter of the sunflower cultivar $\mathrm{H} 358$ at the dose of $44.9 \mathrm{~kg} \mathrm{ha}^{-1}$ of $\mathrm{N}$ reported by Biscaro et al. (2008). In this context, Ivanoff et al. (2010) claim that adequate $\mathrm{N}$ fertilisation management promotes increments of approximately $16 \%$ in the mean diameter of sunflower capitulum; this was also observed by Siddiqui et al. (2009) in different sunflower cultivars.

The interaction of water salinity $\mathrm{x} N$ levels did not significantly affect any of the production components (Table 1). However, the production of achenes showed an isolated response to the effects of water salinity and $\mathrm{N}$ levels, while the mass of 1,000 achenes (M1000A) and the oil content of the achenes responded to $\mathrm{N}$ levels and the oil yield to water salinity (Table 2). These results confirm that the different parameters of a plant show different responses to the effects of water salinity, and $\mathrm{N}$ may or may not have positive effects on the production of sunflower irrigated with saline waters. 


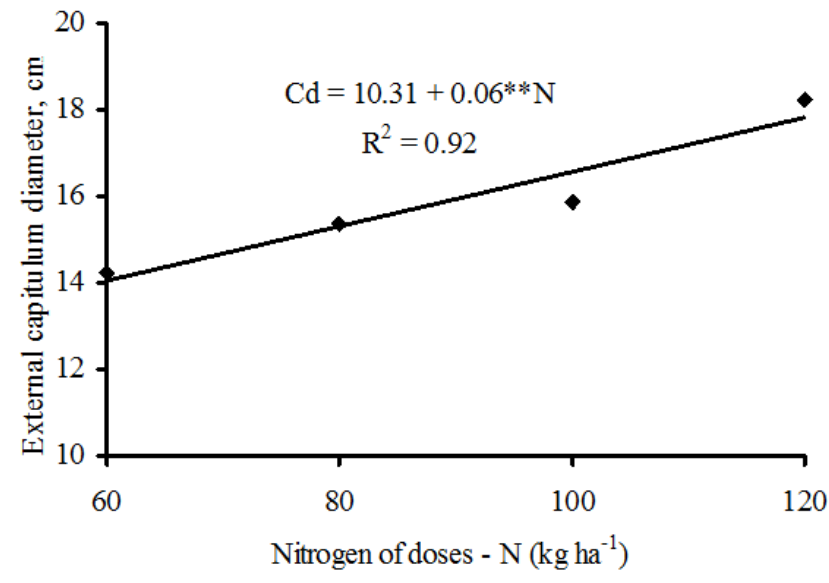

Figure 3. External capitulum diameter (DCAP) of sunflower cv. 'Embrapa 122-V2000' as a function of nitrogen fertilisation.

Table 2. ANOVA summary for the mass of 1,000 achenes (M1000A), productivity (PRO), oil content (OC) and oil yield (OY) of sunflower, cv. 'Embrapa 122-V2000', cultivated under different levels of irrigation water salinity and nitrogen fertilisation.

\begin{tabular}{|c|c|c|c|c|c|}
\hline \multirow{2}{*}{ Variation source } & \multirow[b]{2}{*}{$\mathrm{DF}$} & \multicolumn{4}{|c|}{ Mean square } \\
\hline & & M1000A & PRO & $\mathrm{OC}$ & OY \\
\hline Blocks & 2 & $500.64^{\mathrm{ns}}$ & $184621.71^{\mathrm{ns}}$ & $14.71^{\mathrm{ns}}$ & $16511.46^{\mathrm{ns}}$ \\
\hline Salinity (S) & 4 & $352.05^{\mathrm{ns}}$ & $497470.68^{*}$ & $3.89^{\mathrm{ns}}$ & $88447.09^{*}$ \\
\hline Linear regression & 1 & $896.94^{\mathrm{ns}}$ & $1984625.42^{* *}$ & $0.42^{\text {ns }}$ & $350374.65^{* *}$ \\
\hline Quadratic regression & 1 & $344.31^{\text {ns }}$ & $408.59^{\mathrm{ns}}$ & $14.19^{\mathrm{ns}}$ & $31.41 .54^{\mathrm{ns}}$ \\
\hline Residue 1 & 8 & 52.09 & 105447.94 & 16.83 & 18303.68 \\
\hline Nitrogen $(\mathrm{N})$ & 3 & $90.01^{*}$ & $247766.55^{* *}$ & $31.32^{*}$ & $11104.16^{\mathrm{ns}}$ \\
\hline Linear regression & 1 & $360.96^{* *}$ & $734778.03^{* *}$ & $90.31^{* *}$ & $32507.93^{\mathrm{ns}}$ \\
\hline Quadratic regression & 1 & $7.35^{\mathrm{ns}}$ & $3153.75^{\text {ns }}$ & $0.00^{\mathrm{ns}}$ & $802.56^{\mathrm{ns}}$ \\
\hline Residue 2 & 30 & 78.61 & 47357.78 & 7.75 & 11353.03 \\
\hline Interaction $(\mathrm{S} \times \mathrm{N})$ & 12 & $8.37^{\mathrm{ns}}$ & $19863.16^{\mathrm{ns}}$ & $3.72^{\mathrm{ns}}$ & $5394.30^{\mathrm{ns}}$ \\
\hline CV1 $1 \%$ & & $13.47^{--}$ & 17.19 & 9.86 & 17.25 \\
\hline $\mathrm{CV} 2(\%)$ & & 14.60 & 11.52 & 6.69 & 13.58 \\
\hline
\end{tabular}

$\mathrm{DF}=$ degrees of freedom; $\mathrm{CV} 1=$ coefficient of variation of the plots; CV2 = coefficient of variation of the subplots; $*$ and $* *=$ significant at 0.01 and 0.05 probability levels, respectively; ns $=$ not significant.

The increase in $\mathrm{N}$ levels promoted linear increment in the mass of 1,000 viable achenes (Figure 4), with an increment of $8.45 \%$ for every 20 $\mathrm{kg} \mathrm{ha}^{-1}$ of $\mathrm{N}$ applied to the soil, from $60 \mathrm{~kg} \mathrm{ha}^{-1}$ of $\mathrm{N}$ onwards. The fact that M1000A was positively influenced by the increment in $\mathrm{N}$ levels may be associated with the $\mathrm{N}$ functions in the metabolism, since this macronutrient participates in the biosynthesis of vital organic compounds. These results are consistent with Lobo et al. (2012), who studied the effect of $\mathrm{N}$ fertilisation on the production of sunflower, Hybrid $\mathrm{H} 251$, and reported an increase of $23.78 \%$ with the increment in the doses from 50 to $300 \mathrm{~kg} \mathrm{ha}^{-1}$ of $\mathrm{N}$ in the mass of one thousand seeds.

Irrigation water salinity inhibited and $\mathrm{N}$ fertilisation increased the productivity of sunflower achenes, as shown in Figure 5. Productivity decreased with a loss of $5.5 \%$ per unit increase in $\mathrm{ECW}$ (Figure 5A). Salt accumulation in the root zone caused by saline water irrigation damages root expansion and plant development, leading to a reduced production of components. This is due to the increment of salinity in the water or in the soil, with negative reflexes in the vegetative and productive behaviour of the crop (GUEDES FILHO et al., 2015). The results of present study differ from those observed by Morais et al. (2011), who concluded that increasing salinity in the irrigation water of up to 3.5 $\mathrm{dS} \mathrm{m}^{-1}$ did not compromise sunflower productivity (Hybrid H251). These different responses to salinity may vary between cultivars of a same species, with phenological stage, strategy of water application and exposure time to the salts (SAVVAS et al., 2007).

Nitrogen fertilisation linearly stimulated the productivity of achenes (Figure $5 \mathrm{~B}$ ), with an increase of $6.86 \%$ for every $20 \mathrm{~kg} \mathrm{ha}^{-1}$ of $\mathrm{N}$ applied to the soil, from $60 \mathrm{~kg} \mathrm{ha}^{-1}$ of $\mathrm{N}$ onwards. Similar results were presented by Lobo et al. (2012), who concluded that the increment in $\mathrm{N}$ levels from 50 to $130 \mathrm{~kg} \mathrm{ha}^{-1}$ increased sunflower productivity from 2,152 to $3,802 \mathrm{~kg} \mathrm{ha}^{-1}$. These results also agree with those of Biscaro et al. (2008), who observed that split $\mathrm{N}$ fertilisation as top-dressing at the doses of 0 to $80 \mathrm{~kg}$ $\mathrm{ha}^{-1}$ increased the productivity of the sunflower cultivar H358 (Dekalb), with the highest value of $2,101 \mathrm{~kg} \mathrm{ha}^{-1}$ at the maximum estimated $\mathrm{N}$ dose of $55 \mathrm{~kg} \mathrm{ha}^{-1}$. 


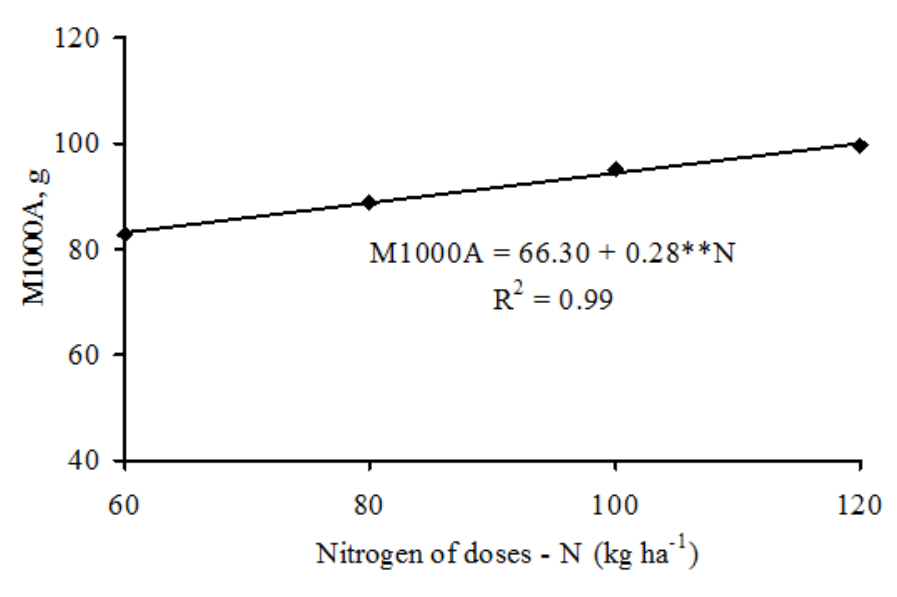

Figure 4. Mass of 1,000 viable achenes of sunflower cv. 'Embrapa 122-V2000', as a function of nitrogen fertilisation.
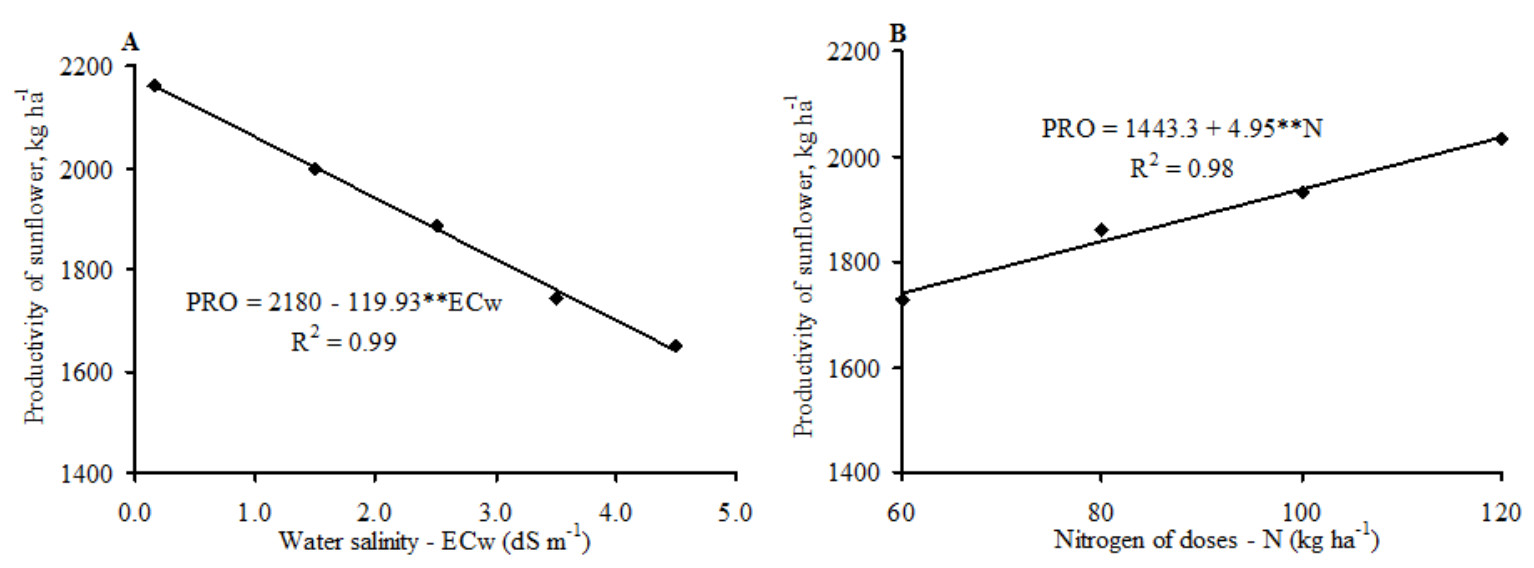

Figure 5. Productivity of sunflower cv. 'Embrapa 122-V2000', as a function of irrigation water salinity (A) and nitrogen fertilisation (B).

The increment in $\mathrm{N}$ levels negatively affected the oil content in the achenes, while the increment in water salinity levels compromised the oil yield of sunflower achenes (Figure 6). An increase in N levels from 60 to $120 \mathrm{~kg} \mathrm{ha}^{-1}$ resulted in a decrease of oil contents from 43.1 to $39.4 \%$ equivalent to a reduction of $2.57 \%$ for every $20 \mathrm{~kg} \mathrm{ha}^{-1}$ of $\mathrm{N}$ applied. According to EMBRAPA (2006), achenes of the sunflower cultivar 'Embrapa 122-V2000' have a mean oil content of $39.9 \%$, i.e. a value lower than that found in the present study when plants were fertilised with $\mathrm{N}$ levels between 60 and $100 \mathrm{~kg} \mathrm{ha}^{-1}$ and higher than that observed under a fertilisation regime of $120 \mathrm{~kg} \mathrm{ha}^{-1}$. This result indicates that $\mathrm{N}$ fertilisation above $60 \mathrm{~kg} \mathrm{ha}^{-1}$, under the studied conditions, may have an antagonistic effect on oil accumulation in sunflower achenes.

Despite the essential functions of $\mathrm{N}$ in the production and in chlorophyll activities of the plants, in general, $\mathrm{N}$ increase compromised the oil content of $H$. annuus (Figure 6A). This behaviour is different from that observed for other achenes and production variables. The oil content in the achenes results from the balanced equilibrium between the production of lipids, proteins and other photoassimilates, depending on the genetic characteristics of the crop. In this context, Lobo et al. (2012) concluded that the increase in $\mathrm{N}$ levels above $70 \mathrm{~kg} \mathrm{ha}^{-1}$ reduces the oil content in sunflower.

As observed for OC (Figure 6A), sunflower oil yield also decreased linearly with the increment in the levels of irrigation water salinity and, based on the regression model (Figure 6B), OY showed decreases of $5.56 \%$ per unit increase in $\mathrm{ECW}$. Especially when plants were subjected to water salinity of $4.5 \mathrm{dS} \mathrm{m}^{-1}$, there was a reduction of $219.19 \mathrm{~kg} \mathrm{ha}^{-1}$ in OY in relation to those irrigated with ECW of $0.15 \mathrm{dS} \mathrm{m}^{-1}$. The reductions in the oil yield of sunflower, cv. 'Embrapa 122-V2000', as a result of the increase in $\mathrm{ECW}$, can be attributed to the lower water absorption due to the reduction in the osmotic potential of the soil solution, caused by the excess of ions, which compromises the entry of water into plant cells, thus reducing $\mathrm{CO}_{2}$ assimilation, stomatal conductance, transpiration and photosynthesis (GULZAR et al., 2003). 

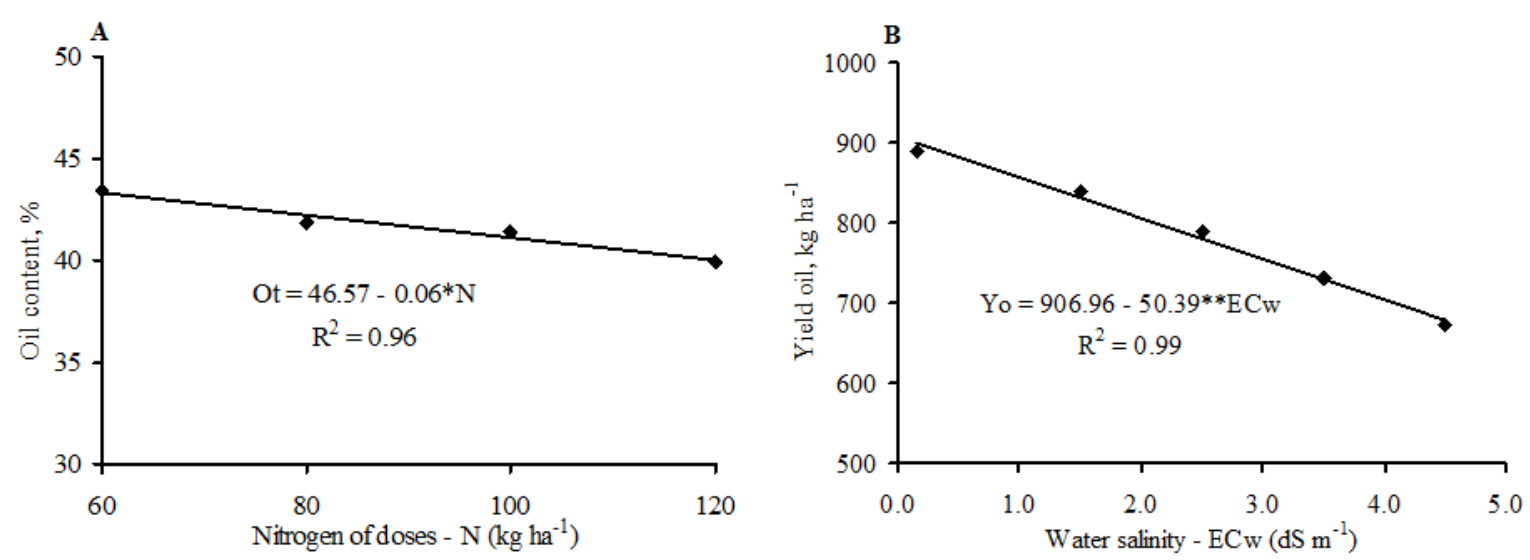

Figure 6. Oil content and yield of sunflower cv. 'Embrapa 122-V2000', as a function of nitrogen fertilisation (A) and irrigation water salinity (B).

\section{CONCLUSIONS}

The interaction between irrigation water salinity and nitrogen fertilisation does not have significant effects on the analysed variables of the sunflower cultivar 'Embrapa 122-V2000'.

The increase in water salinity from $0.15 \mathrm{dS}$ $\mathrm{m}^{-1}$ negatively affects the total number of achenes and the percentage of viable achenes, productivity and oil yield of the sunflower cultivar 'Embrapa 122-V2000'.

The increase in nitrogen levels stimulates the total number of achenes and the number of viable achenes, mass of 1,000 achenes, capitulum diameter and the productivity of achenes, and inhibits the oil content in the achenes of the sunflower cultivar 'Embrapa 122-V2000'.

Nitrogen levels of up to $100 \mathrm{~kg} \mathrm{ha}^{-1}$ promote adequate oil content in the achenes of the sunflower cultivar 'Embrapa 122-V2000'.

\section{REFERENCES}

AYRES, R. S.; WESTCOT, D. W. A qualidade da água na agricultura. 2. ed. Campina Grande, $\mathrm{PB}$ : UFPB. 1999. 153 p.

BISCARO, G. A. et al. Adubação nitrogenada em cobertura no girassol irrigado nas condições de Cassilândia- MS. Ciência e Agrotecnologia, Lavras, v. 32, n. 5, p. 1366-1373, 2008.

CAMPOS, V. B.; CHAVES, L. H. G.; GUERRA, H. O. C. Adubação com NPK e irrigação do girassol em Luvissolo: Comportamento vegetativo. Revista Ambiente \& Água, Taubaté, v. 10, n. 1, p. 221-233, 2015.

CHAVES, L. H. G.; GHEYI, H. R.; RIBEIRO, S. Consumo de água e eficiência do uso para cultivar de mamona Paraguaçu submetida à fertilização nitrogenada. Revista Engenharia Ambiental, Espírito Santo do Pinhal, v. 8, n. 1, p. 126-133, 2011.

COELHO, M. A.; SONCIN, N. B. Geografia do Brasil. São Paulo, SP: Moderna. 1982. 368p.

CONNOR, J. D.; HALL, A. J. Sunflower physiology. In: SCHNEIDER. A. A. (Eds.).Sunflower technology and production. Madison. ASA/CSSA/SSSA. 1997. p.113-181. (Series of Monographs, 35).

CORREIA, K. G. et al. Crescimento. produção e características de fluorescência da clorofila a em amendoim sob condições de salinidade. Revista Ciência Agronômica, Fortaleza, v. 40, n. 4, p. 514-521, 2009.

DONAGEMA, G. K. et al. Manual de métodos de análise de solo. 2. ed. Rio de Janeiro, RJ: Embrapa Solos. 2011. 230 p.

EMBRAPA - Empresa Brasileira de Pesquisa Agropecuária. Girassol Embrapa 122/V-2000. 1. ed. Londrina. 2006. 2 p.(Folder n. 04/2006).

FAGERIA, N. K. Solos tropicais e aspectos fisiológicos das culturas. Brasília, DF: EMBRAPA. 1989. $425 \mathrm{p}$.

FERREIRA, D. F. SISVAR 4.6 - Sistema de análises estatísticas. Lavras, MG: UFLA. 2011. $32 \mathrm{p}$.

FLORES, P.; CARVAJAL,M.; MARTINEZ, V. Salinity and ammonium/nitrate interactions on tomato plant development.nutrition. and metabolites. Journal of Plant Nutrition, Oxford, v. 24, n. 10, p. 1561-1573, 2001.

FREITAS, C. A. et al. Crescimento da cultura do girassol irrigado com diferentes tipos de água e adubação nitrogenada. Revista Brasileira de 
Engenharia Agrícola e Ambiental, Campina Grande, v. 16, n. 10, p. 1031-1039, 2012.

GUEDES FILHO,. D. H. et al. Componentes de produção e rendimento do girassol sob irrigação com águas salinas e adubação nitrogenada. Revista Irriga, Botucatu, v. 20, n. 3, p. 514-527, 2015.

GUEDES FILHO, D. H. et al. Production of sunflower and biomass depending on available soil water and nitrogen levels. Iranica Journal of Energy \& Environment, Tehran, v. 2, n. 4, p. 313-319, 2011.

GULZAR, S.; KHAN, M. A.; UNGAR,I. A. Salt tolerance of a coastal salt marsh grass. Communications in Soil Science and Plant Analysis, New York, v. 34, n. 17-18, p. 2595-2605, 2003.

IVANOFF, M. E. et al. Formas de aplicação de nitrogênio em três cultivares de girassol na Savana de Roraima. Revista Ciência Agronômica, Fortaleza, v. 41, n. 3, p. 319-325, 2010.

LAVRES JUNIOR, J. et al. Deficiência de macronutrientes no estado nutricional da mamoneira cultivar Iris. Pesquisa Agropecuária Brasileira, Brasília, v. 40, n. 2, p.145-151, 2005.

LIMA, G. S. et al. Crescimento e componentes de produção da mamoneira sob estresse salino e adubação nitrogenada. Engenharia Agrícola, Jaboticabal, v. 34, n. 5, p. 854-866, 2014.

LOBO, T. F.; GRASSI FILHO, H. Níveis de lodo de esgoto na produtividade do girassol. Journal of Soil Science and Plant Nutrition, Temuco, v. 7, n. 3, p. 16-25, 2007.

LOBO, T. F.; GRASSI FILHO, H.; COELHO, H. A.Efeito da adubação nitrogenada na produtividade do girassol. Científica, Botucatu, v. 40, n. 1, p. 59-68, 2012.

MALIK, M. A. et al. Suitable level of N. P and K for harvesting the maximum economic returns of sunflower (Helianthus annuus L.). International Journal of Agriculture \& Biology, Beijing, v. 6, n. 2 , p. $240-242,2009$.

MESQUITA, F. O. et al. Produção de mudas de maracujazeiro amarelo em substrato com biofertilizante bovino irrigado com águas salinas. Revista Agropecuária Técnica, Areia, v. 31, n. 2, p. 134-142, 2010.

MORAIS, F. A. et al. Influência da irrigação com água salina na cultura do girassol. Revista Ciência Agronômica, Fortaleza, v. 42, n. 2, p. 327-336,
2011.

MUNNS, R.; TESTER, $\quad \mathrm{M}$ Mechanisms of salinity tolerance. Annual Review of Plant Biology, Boca Raton, v. 59, n. 1, p. 651$681,2008$.

NOBRE, R. G. et al. Crescimento e floração do girassol sob estresse salino e adubação nitrogenada. Revista Ciência Agronômica, Fortaleza, v. 41, n. 3 , p. 358-367, 2010.

PAZ, L. M. Ressonância magnética nuclear (RMN). princípios e aplicações. Óleos \& Grãos, Belo Horizonte, v. 7, n. 33, p. 32-33, 1996.

RHOADES, J. D.; KANDIAH, A.; MASHALI,A. $M$. Uso de águas salinas para produção agrícola. Campina Grande: UFPB. 2000. 117p. (Estudos da FAO. Irrigação e Drenagem).

RODRIGUES, G. C. et al. Relating energy performance and water productivity of sprinkler irrigated maize. wheat and sunflower under limited water availability. Biodiesel Engineering, Oxford, v. 106 , n. 2 , p. $195-204,2010$

SACHS, L. G. et al. Efeito de NPK na produtividade e componentes químicos do girassol. Semina: Ciências Agrárias, Londrina, v. 27, n. 4 , p. 533-546, 2006.

SANTOS JÚNIOR, J. A. et al. Cultivo de girassol em sistema hidropônico sob diferentes níveis de salinidade. Revista Ciência Agronômica, Fortaleza, v. 42, n. 4, p. 842-849, 2011.

SAVVAS, D. et al.Interactions between salinity and irrigation frequency in greenhouse pepper grown in closed-cycle hydroponic systems. Agricultural Water Management, Amsterdam, v. 91, n. 1-3, p. 102-111, 2007.

SIDDIQUI, M. H. et al. Effect of NPK micronutrients and N-placement on the growth and yield of sunflower. Sarhad Journal of Agriculture, Peshawar, v. 25, n. 1, p. 45-52, 2009.

SILVA, T. G. F. et al. Crescimento do girassol ornamental cultivado em ambiente protegido sob diferentes níveis de condutividade elétrica de fertirrigação. Revista Ceres, Viçosa, v. 56, n. 5, p. $602-610,2009$.

SMIDERLE, O. J. Orientações gerais para o cultivo do girassol em Roraima. Boa vista: Embrapa Roraima. 2000. 2 p. (Embrapa informa 8).

TAIZ, L.; ZEIGER, E. Fisiologia vegetal. 5. ed. Porto Alegre, RS: Artmed. 2013. 918p. 
TRAVASSOS, K. D. et al. Produção de aquênio do girassol irrigado com água salobra. Revista Brasileira de Engenharia Agrícola e Ambiental, Campina Grande, v. 15, n. 4, p.371-376, 2011.

ZOBIOLE, L. H. S. et al. Marcha de absorção de macronutrients na cultura do girassol. Revista Brasileira de Ciência do Solo, Viçosa, v. 34, n. 2, p. 425-433, 2010. 